\title{
Management Options for Extensor Mechanism Discontinuity in Patients With Total Knee Arthroplasty
}

\author{
Parth Vyas ${ }^{1}$, Quanjun Cui ${ }^{2}$ \\ 1. Orthopedic Surgery, University of North Dakota/Sanford Health, Fargo, USA 2. Orthopedic Surgery, University of \\ Virginia Health System, Charlottesville, USA
}

Corresponding author: Parth Vyas, drparthvyas@gmail.com

\begin{abstract}
Extensor mechanism disruption is one of the most dreaded complications of total knee arthroplasty. At times, the disruption is associated with infection, the paucity of soft tissue, and loosening of implants. Treatment decisions made by surgeons are guided by their experience and expertise. The purpose of this article is to provide the readers with an evidence-based comprehensive review which, in turn, should help them in diagnosis and selecting the best treatment strategy for individual patients.
\end{abstract}

In the following article, we have discussed extensor mechanism disruptions of varying severity at various anatomical levels. We also covered both operative and non-operative measures in different clinical situations.

The analysis of various articles published in the literature would also help orthopedic surgeons to understand the probable outcomes of the particular treatment option chosen and to counsel their patients accordingly.

Received 05/27/2020

Review began 06/09/2020 Review ended 06/28/2020 Published 07/16/2020

(c) Copyright 2020 Vyas et al. This is an open access article distributed under the terms of the Creative Commons Attribution License CC-BY 4.0., which permits unrestricted use, distribution, and reproduction in any medium, provided the original author and source are credited.
Categories: Orthopedics, Trauma

Keywords: knee, extensor mechanism, knee replacement, patellar tendon rupture, discontinuity, total knee replacement

\section{Introduction And Background}

The extensor mechanism of the knee joint is one of the most important structures encountered during total knee arthroplasty. It consists of the quadriceps tendon, patella, and patellar tendon. The importance of extensor mechanism is well-established in the field of knee replacement, not only in terms of minimizing intraoperative complications but also in early postoperative recovery and in attaining long-term goals. The structural and functional integrity of the extensor mechanism is crucial for optimum biomechanics of both the native and prosthetic knee. Restoration of the optimum Q-angle is necessary to obtain desirable patellar tracking and to minimize the chances of anterior knee pain [1].

One of the major steps during any knee replacement surgery is to retract the extensor mechanism in a way that minimizes damage to the structural and functional integrity of the extensor mechanism and, at the same time, to obtain adequate exposure to performing all the necessary procedures. All the contemporary approaches to the knee joint revolve around how to handle the extensor mechanism during the surgery and how to ensure the optimum function of the extensor mechanism postoperatively. The rationale presented by surgeons using subvastus and midvastus approaches is that they are less damaging to the extensor mechanism and hence help in faster recovery [2].

For revision cases, the biggest obstacle in attaining proper exposure is stiff and sometimes deficient extensor mechanism. Extensive approaches like the rectus snip, V-Y quadricepsplasty, and tibial tubercle osteotomy have been described in the literature for such cases [3]. These extensile approaches help the surgeon to obtain adequate exposure in performing such complex procedures.

Extensor mechanism dysfunction in the recipients of total knee arthroplasty can result from various causes ranging from iatrogenic to post-traumatic disruption. This dysfunction can be acute, subacute, or chronic and can involve any of the anatomical components of the extensor mechanism. Sometimes extensor mechanism disruption is combined with other complications, such as infection, periprosthetic fracture, loose implants, and failed previous reconstructions. These coexisting conditions have profound implications on the management and outcomes of extensor mechanism repair. Adequate repair or reconstruction of the extensor mechanism is considered paramount for the success of knee replacement in such cases.

Based on all the aforementioned factors, there are numerous management strategies described in the literature to treat this rare but devastating complication [1-35]. To date, there is no consensus amongst 
orthopedists regarding ideal treatment for extensor mechanism deficiency, especially in chronic cases. Treatment decisions made by surgeons largely depend upon individual training, experience, and preferences rather than evidence-based guidelines.

The purpose of this review is to summarize the existing literature regarding extensor mechanism reconstruction and provide the readers an evidence-based summary of etiology, diagnosis, and techniques for extensor mechanism reconstruction and outcomes of various strategies to treat this catastrophic condition.

\section{Review}

\section{Material and methods}

We searched the PubMed database using "extensor mechanism disruption" and "total knee arthroplasty (TKA)" as keywords. Resultant articles were filtered based on human subjects, English language, and clinical studies. All the remaining articles were manually scanned by the authors for their relevance to the subject. The resultant 35 articles were thoroughly reviewed for their entire content and classifications; etiology and management portions of the articles were derived based on the evidence portrayed in the selected articles.

\section{Classification}

Extensor mechanism disruptions can be further categorized based upon location, extent, or chronicity of the disruption. Extensor mechanism disruption can occur at the level of the quadriceps tendon, patella, or patellar tendon, and management options may vary accordingly (Figure 1).

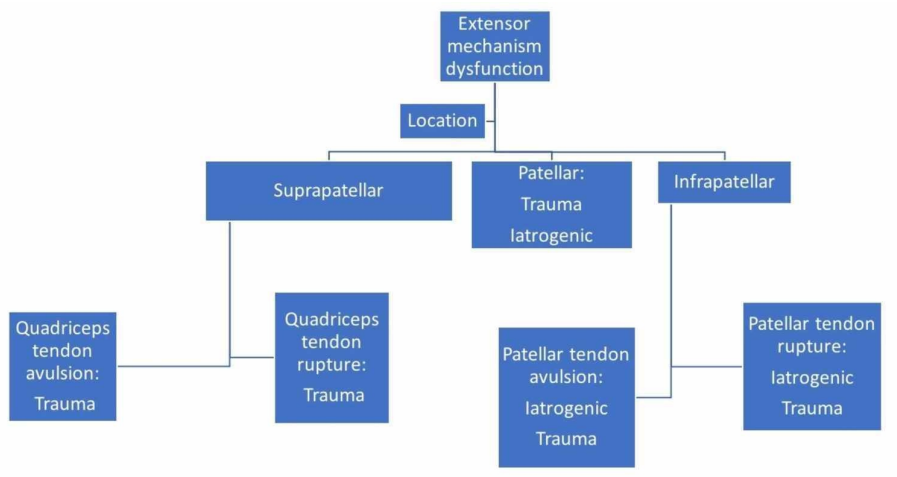

FIGURE 1: Anatomical classification of extensor mechanism disruption

Patellar tendon disruptions are the most common and the most devastating form of extensor mechanism dysfunction, mainly because of the poor soft tissue coverage, lack of adequate blood supply, and resultant extremely high incidence of failures and considerable reoperation rates [4].

\section{Etiology}

The etiology of the dysfunction has a great influence on the management and outcomes. Acute traumatic disruptions are relatively easier to treat since scarring and retraction of the extensor mechanism is minimal and primary repair is still an option in many such cases, while chronic or failed reconstructions are often associated with infection or loosening of components. These cases are less amenable to primary repair, and failure rates and complications are higher.

Suprapatellar disruptions result from either a quadriceps tendon rupture or avulsion from the superior pole of the patella. It is a rare complication in comparison to patellar tendon rupture or avulsion. The estimated incidence is $0.1 \%$ amongst total knee replacement recipients [5]. While trauma is often considered as a trigger event, there are some predisposing factors that increase the risk of rupture in individuals (Table 1) [68]. 


\title{
Cureus
}

\begin{tabular}{|l|l|}
\hline Systemic Risk Factors & Local Risk Factors \\
\hline Rheumatoid arthritis & Prior knee arthroplasty \\
\hline Diabetes mellitus & Arthrotomy \\
Chronic renal failure & Multiple steroid injections \\
Obesity & Patellar malpositioning \\
Hyperthyroidism & Lateral retinacular release at the time of the arthroplasty \\
\hline
\end{tabular}

TABLE 1: Risk Factors for Quadriceps Tendon Rupture

Periprosthetic fracture of the patella is the second most common periprosthetic fracture around the knee joint after distal femur fracture [9]. The estimated average incidence is $1.19 \%$ [10]. It is one of the most difficult fractures to treat. It is worth noting that only about $12 \%$ of these fractures are associated with trauma [11]. Most of these present at routine follow-up with anterior knee pain with or without extensor lag. Most of these fractures are the result of osteonecrosis of the patella. The etiology of almost all of these fractures is iatrogenic.

\begin{abstract}
There are some risk factors associated with periprosthetic patella fracture. The fact that $99 \%$ of these fractures happen in a resurfaced patella shows that resurfacing of the patella is a prominent risk factor. This phenomenon challenges the wisdom behind the practice of resurfacing every patella routinely during primary TKA. The residual thickness of the patella is a known contributor to the risk of fracture.

Traditionally, at least $12 \mathrm{~mm}$ of the thickness of the residual patella is considered adequate to resurface the patella. This signifies the importance of measuring the thickness of the patella before proceeding with a bony resection. A lateral release to improve patella tracking is detrimental to the blood supply to the patella. This becomes more important in the setting of arthroplasty where the medial parapatellar arthrotomy has already jeopardized the medial blood supply. An additional release laterally can render the patella completely avascular and results in osteonecrosis of the patella and resultant stress fracture. All care must be taken to identify and protect the superior lateral genicular artery while performing lateral release. For reasons not clearly understood, cementless components are associated with an increased incidence of fractures. The components with a large central peg create a stress riser and increase the risk of fracture [1011]. Component malalignment alters the biomechanics of the knee joint, increases the stress on the prosthetic patellar component, and indirectly increases the chances of fracture [12-13].
\end{abstract}

These fractures most commonly occur in the first two years after surgery with an average time period being 18.5 months [10].

Ortiguerra and Berry classified periprosthetic patella fracture in three types. Their classification is based on the integrity of the extensor mechanism, the presence or absence of loosening of the component, and the remaining bone stock [10,13-14]. This classification, with the relative incidence of individual types of fractures, is depicted in Table 2.

\begin{tabular}{|l|l|}
\hline Type & Description \\
\hline Type I & Intact extensor mechanism and stable implant $(25.3 \%)$ \\
\hline Type II & Disruption of extensor mechanism with or without implant in place (20\%) \\
Type III & Intact extensor mechanism and loosening of the patellar component (54.7\%) \\
A & Reasonable remaining bone stock \\
B & Poor bone stock \\
\hline
\end{tabular}

TABLE 2: Ortiguerra and Berry Classification of Periprosthetic Patellar Fracture

Most of the patellar tendon avulsions or ruptures can be considered iatrogenic, resulting from either direct injury during the surgery or component malalignment putting excessive stress on the patellar tendon during 


\section{Cureus}

successive ambulation [15]. Patellar tendon rupture or avulsion is one of the most dreaded complications associated with total knee arthroplasty. Regardless of the treatment modality used, the outcomes are unsatisfactory. To prevent these injuries, it is important to prevent excessive stress on the patellar tendon and, if needed, to perform adequate arthrolysis or to switch to extensile approaches, like V-Y quadricepsplasty or rectus snip, at the appropriate time to prevent rupture or avulsion of the patellar tendon [16]. In some instances, nonunion of the tibial tubercle osteotomy used as an extensile approach can lead to patellar tendon insufficiency.

\section{Diagnosis}

Regardless of the etiology and anatomic location, the diagnosis is mainly clinical. In many cases, the diagnosis is delayed or missed altogether due to a lack of suspicion. Patients with extensor mechanism dysfunction typically present with loss of active extension, instability, and quadriceps minus gait. Patients have difficulty in climbing stairs. A history of trauma is commonly present but should not be overemphasized since, in many cases, it cannot be directly linked to the clinical picture. Anterior knee pain is a common presentation in patients with patella fractures with or without extensor lag, depending upon the degree of displacement and continuity of the extensor mechanism. In many cases, especially with complete disruption of the extensor mechanism, a palpable defect virtually confirms the diagnosis (Figure 2).

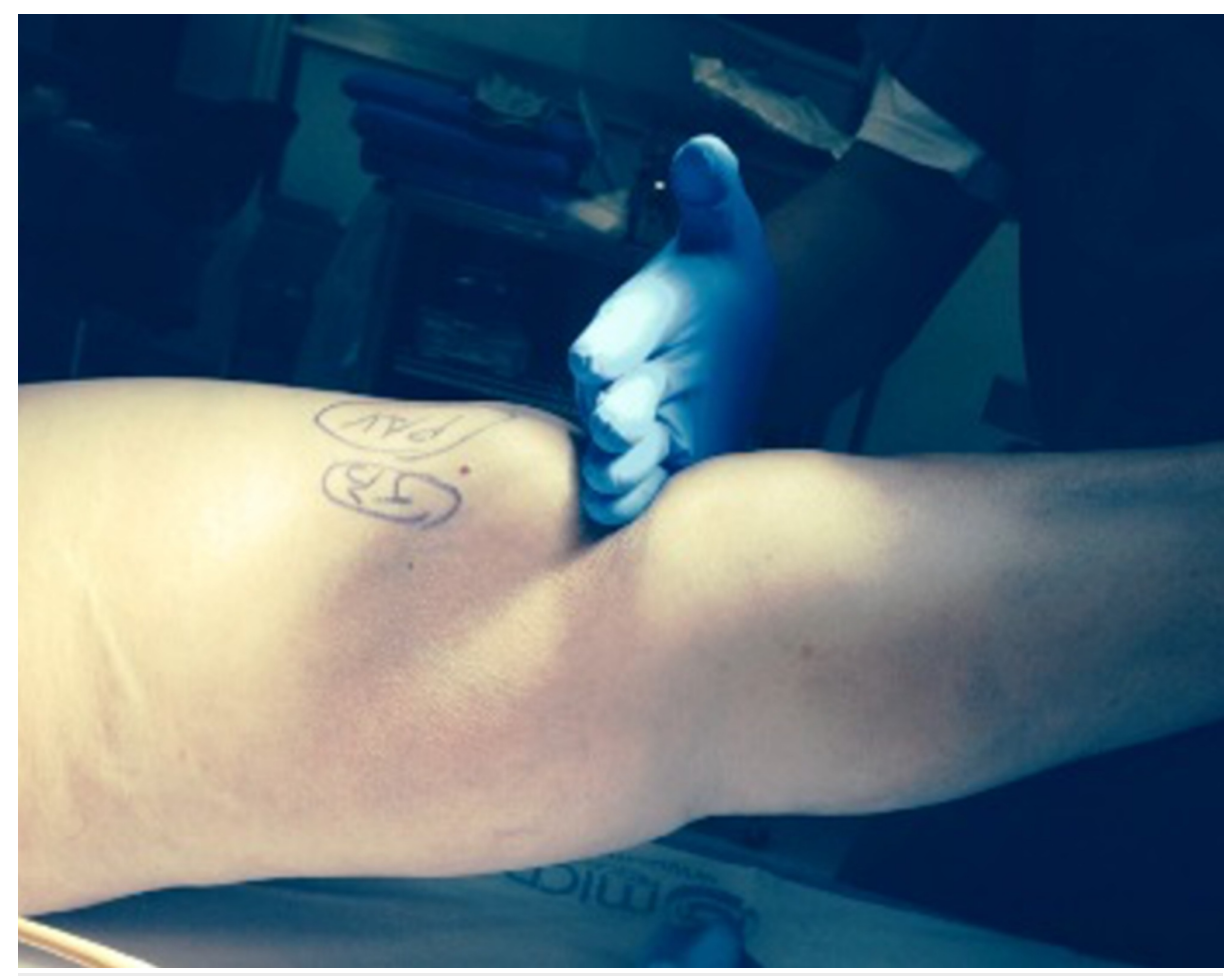

FIGURE 2: Palpable defect in the infrapatellar region at the site of patellar tendon disruption

In cases of a complete patellar tendon disruption, the patella alta is also an important clinical finding.

Apart from the degree of extensor lag and instability, a thorough history and clinical examination also help in determining the future surgical approach, availability of local soft tissue and flaps, the blood supply to the region, the presence or absence of infection, the necessity of additional procedures (e.g., revision of one or more components), medical comorbidities, and probable outcomes.

The clinical diagnosis can be further validated by appropriate radiological studies. A plain x-ray is usually sufficient in this regard. Direct evidence of extensor mechanism disruption can be seen on plain x-ray in the form of patella alta (patellar tendon disruption), tibial tuberosity avulsion, patellar fracture, nonunion or displacement of tibial tubercle osteotomy, or an anteriorly displaced patella (quadriceps tendon disruption). Imaging studies confirm the diagnosis and provide important information about component alignment, fixation of the component, and remaining bone stock. Magnetic resonance imaging (MRI) with special sequences or ultrasound may be helpful in some selected cases but are not routinely required.

The optimum treatment strategy is devised based on all the inputs from the patient's history, physical 
examination, and imaging studies. The final treatment strategy not only depends upon location and degree of extensor mechanism disruption but also on preexisting medical conditions, previous attempts at reconstructions, and expected overall outcomes.

\section{Management}

Quadriceps Tendon Rupture or Avulsion

Incomplete ruptures can be treated non-operatively with acceptable results. In patients with less than a 20degree extensor lag, incomplete ruptures can be treated with immobilization of the knee in extension for four to six weeks, either in a cast or in a brace, followed by gradual mobilization and physical therapy [5, 17]. A study done by Dobbs et al. showed that $85 \%$ of cases with partial quadriceps tendon ruptures yielded satisfactory outcomes with non-operative treatment. This is in contrast to the operative treatment of partial ruptures, which yields satisfactory outcomes in about $75 \%$ of cases. The same study shows satisfactory outcomes in only $40 \%$ of cases with complete ruptures. These results signify the importance of adequately protecting partial ruptures and thus preventing them from being converted to complete ruptures [5].

When extensor lag is more than 20 degrees, operative intervention is necessary. For acute ruptures, primary repair following thorough debridement of the severed ends is recommended. Typically, Krackow sutures are placed in the quadriceps tendon and it is attached to the patella using either drill holes or suture anchor. Biomechanically suture anchor repairs are considered more robust [18]. For chronic ruptures, the primary repair is often impossible owing to the contracture of the surrounding tissue and retraction of the extensor mechanism. In such cases, autologous augmentation using the vastus medialis, vastus lateralis, and medial head of the gastrocnemius can be used [4, 18]. In most cases, local augmentation is not sufficient because of the compromised soft tissue envelope and vascularity. However, it is proven that when a repair is augmented with the medial head of the gastrocnemius with or without the medial part of the soleus extensor lag is less pronounced in comparison to vastus medialis and lateralis flap advancement alone [5]. Results reported by Dobbs et al. are discouraging with a $35 \%$ reoperation rate and $12 \%$ infection rate. Forty percent of the primary suture repairs had re-ruptured [5]. These results are in stark contrast with the generally good results reported in patients without knee replacement [20]. These differences can probably be explained by a compromised soft tissue envelope, higher infection rates, comorbidities, and a relatively older patient population in knee replacement recipients. Chronic and severe deficiency of the quadriceps tendon can be managed by an Achilles tendon allograft with calcaneal tuberosity bone block, extensor mechanism allograft, or patellar tendon allograft. Recently, the use of Marlex mesh has also been popular, which is discussed in detail in the section of patellar tendon disruptions. Results of operative interventions of chronic rupture and resulting insufficiency are far less than satisfactory.

Even after surgical repair, immobilization in extension for a period of four to six weeks, followed by gradual mobilization, is recommended to protect the repair.

\section{Patellar Fracture}

While considering various treatment options, it should be clearly understood that these fractures are different than traumatic patellar fractures in a native knee. Outcomes of open reduction and internal fixation (ORIF) are poor in these patients [10]. Reasons for this discrepancy in results lie in the fact that these fractures occur in the background of poor vascularity, low residual bone stock, and altered biomechanics (Figures 3-5). 


\section{Cureus}

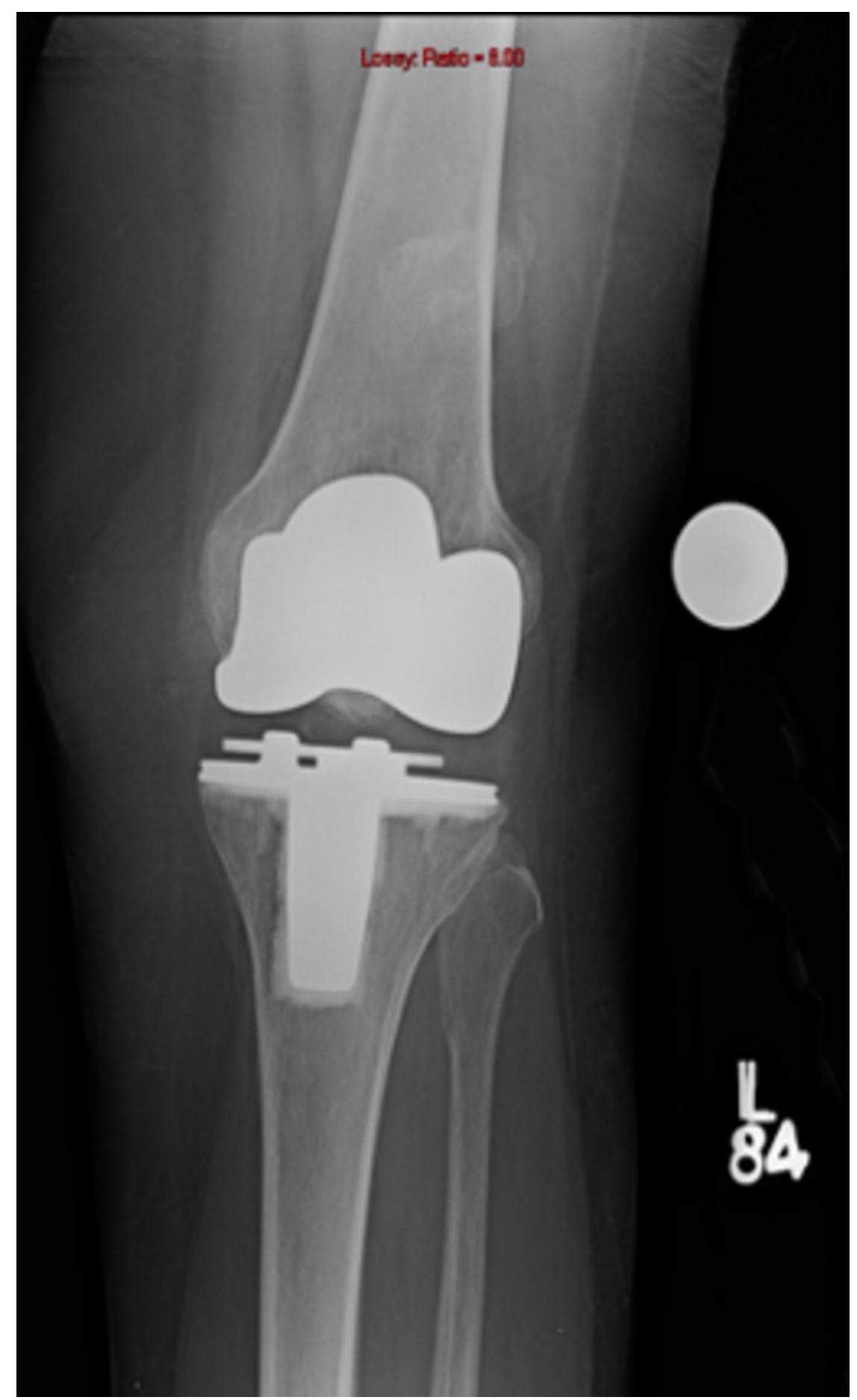

FIGURE 3: Periprosthetic patellar fracture, anteroposterior view 


\section{Cureus}

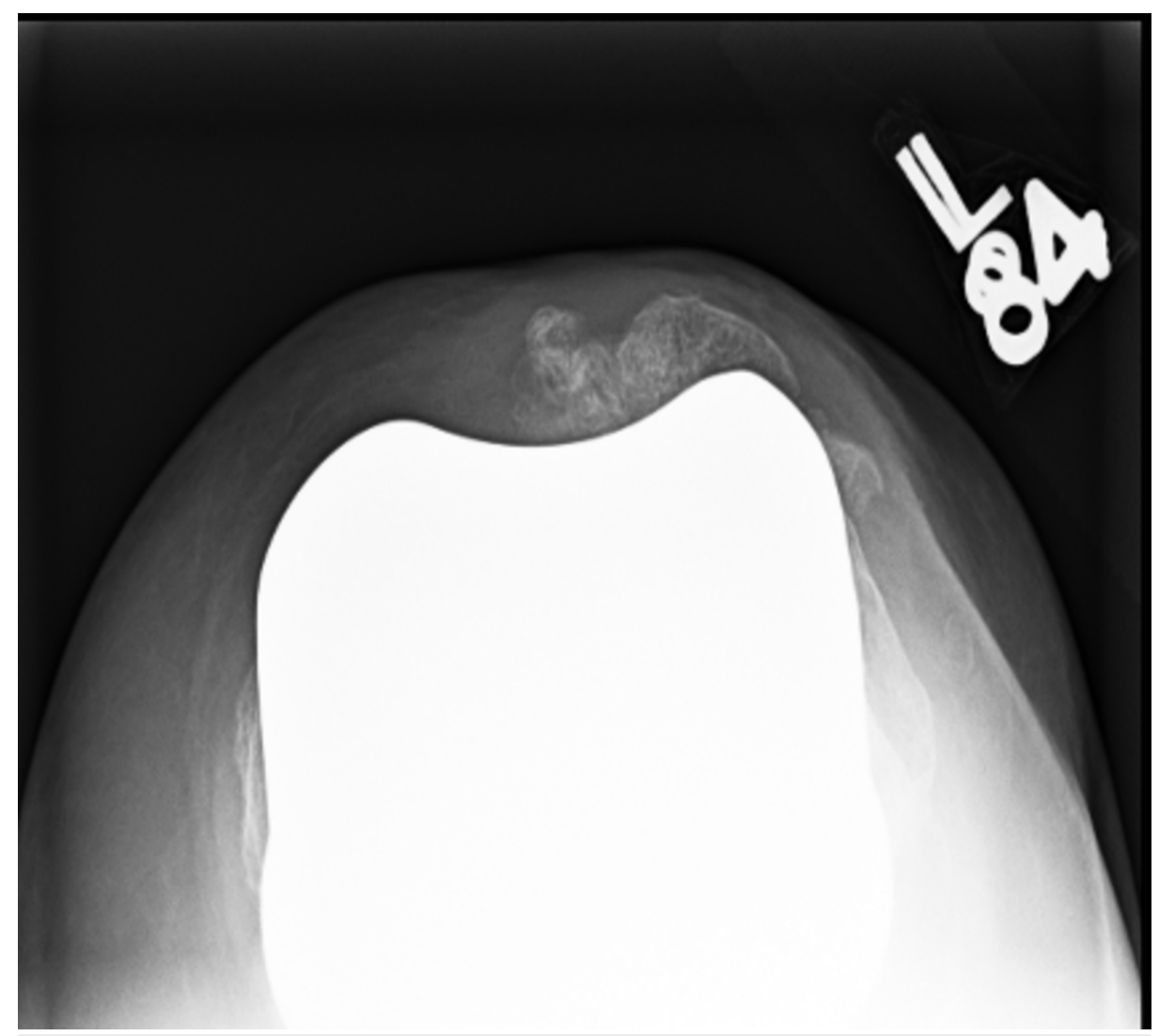

FIGURE 4: Periprosthetic patellar fracture, merchant view

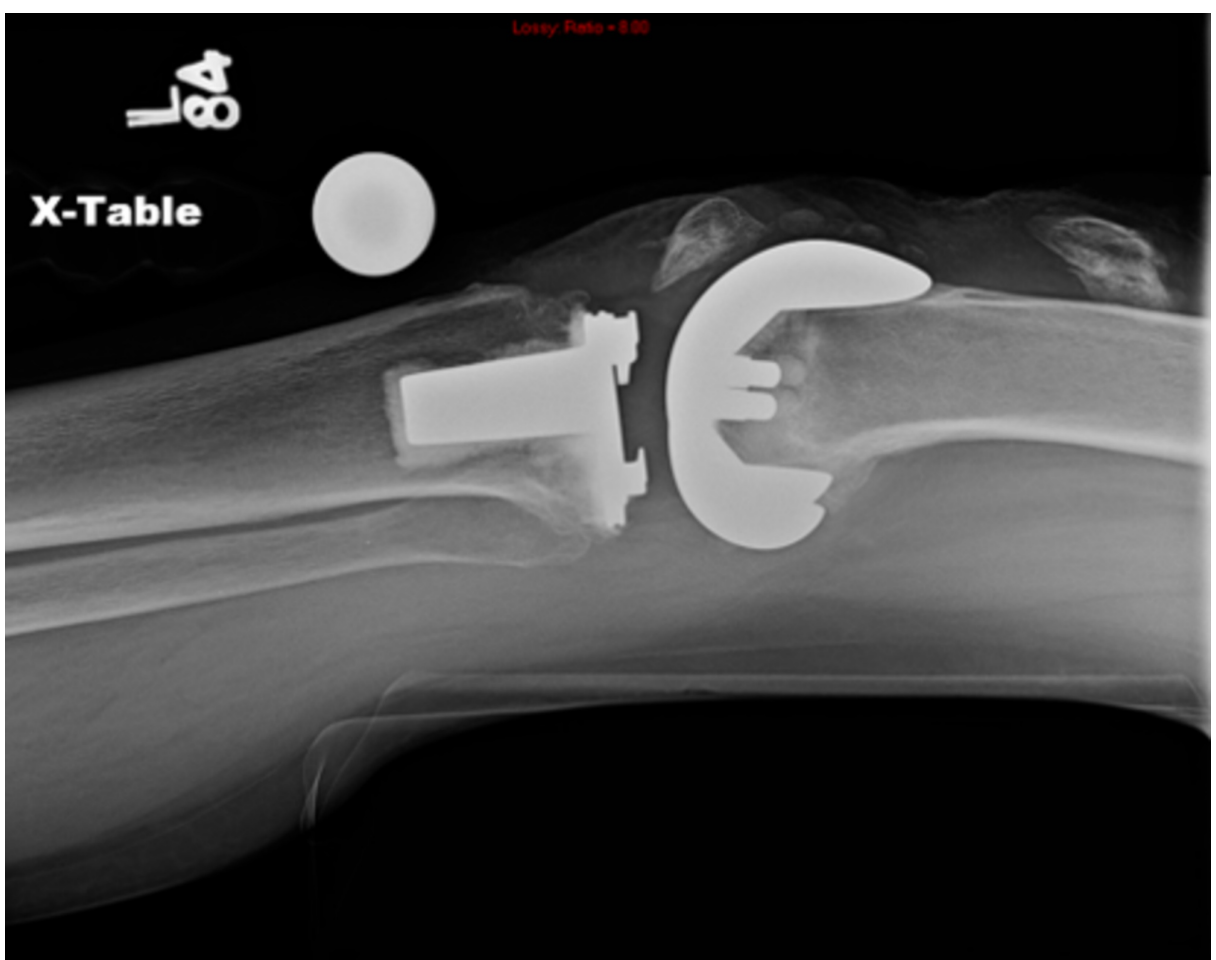

FIGURE 5: Periprosthetic patellar fracture, lateral view

Patients with acceptable quadriceps function and well-fixed components can be treated conservatively in the same manner as a quadriceps tendon rupture [10]. Non-operative treatment yields satisfactory results in most patients as per Keating et al. [11]. Mean flexion achieved was around 120 degrees with less than 5 


\section{Cureus}

degrees of extensor lag and minimal pain in most of their patients.

Operative treatment is associated with a guarded prognosis. ORIF is associated with an $88 \%$ failure rate (Figures 6-7) [10].

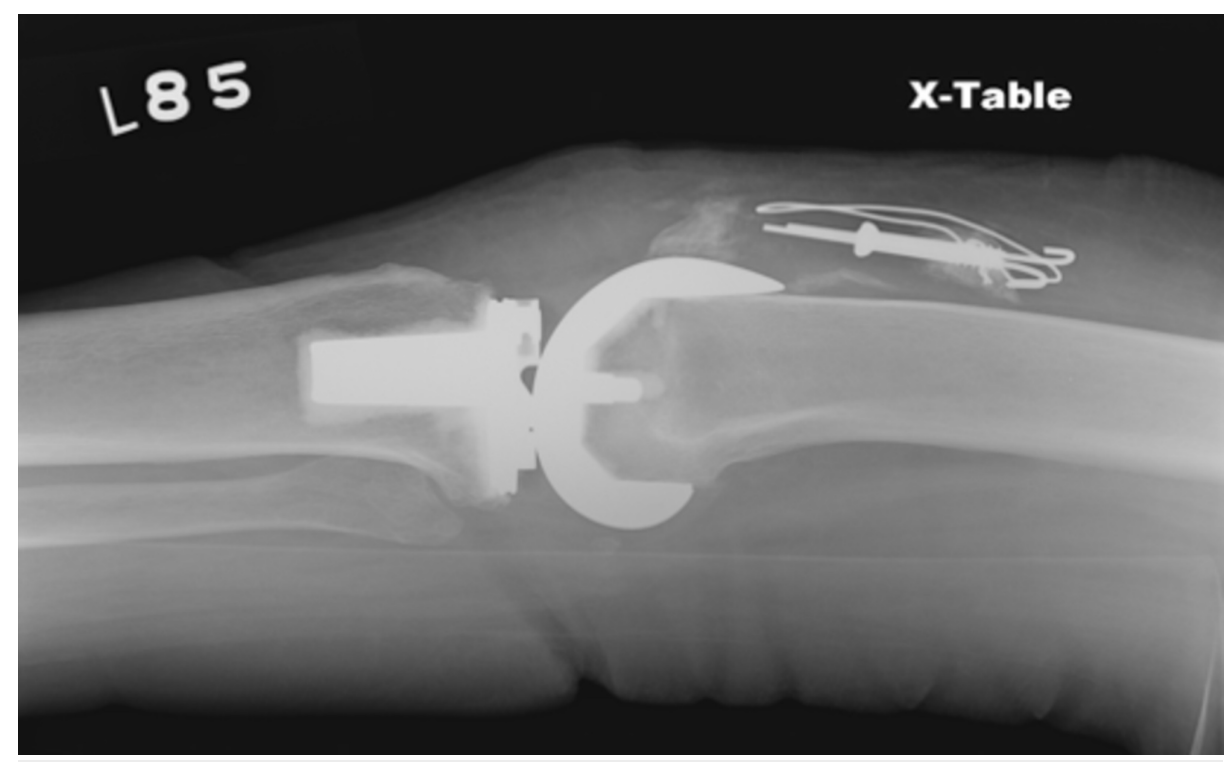

FIGURE 6: Failed open reduction and internal fixation performed for periprosthetic patellar fracture (lateral view) 


\section{Cureus}

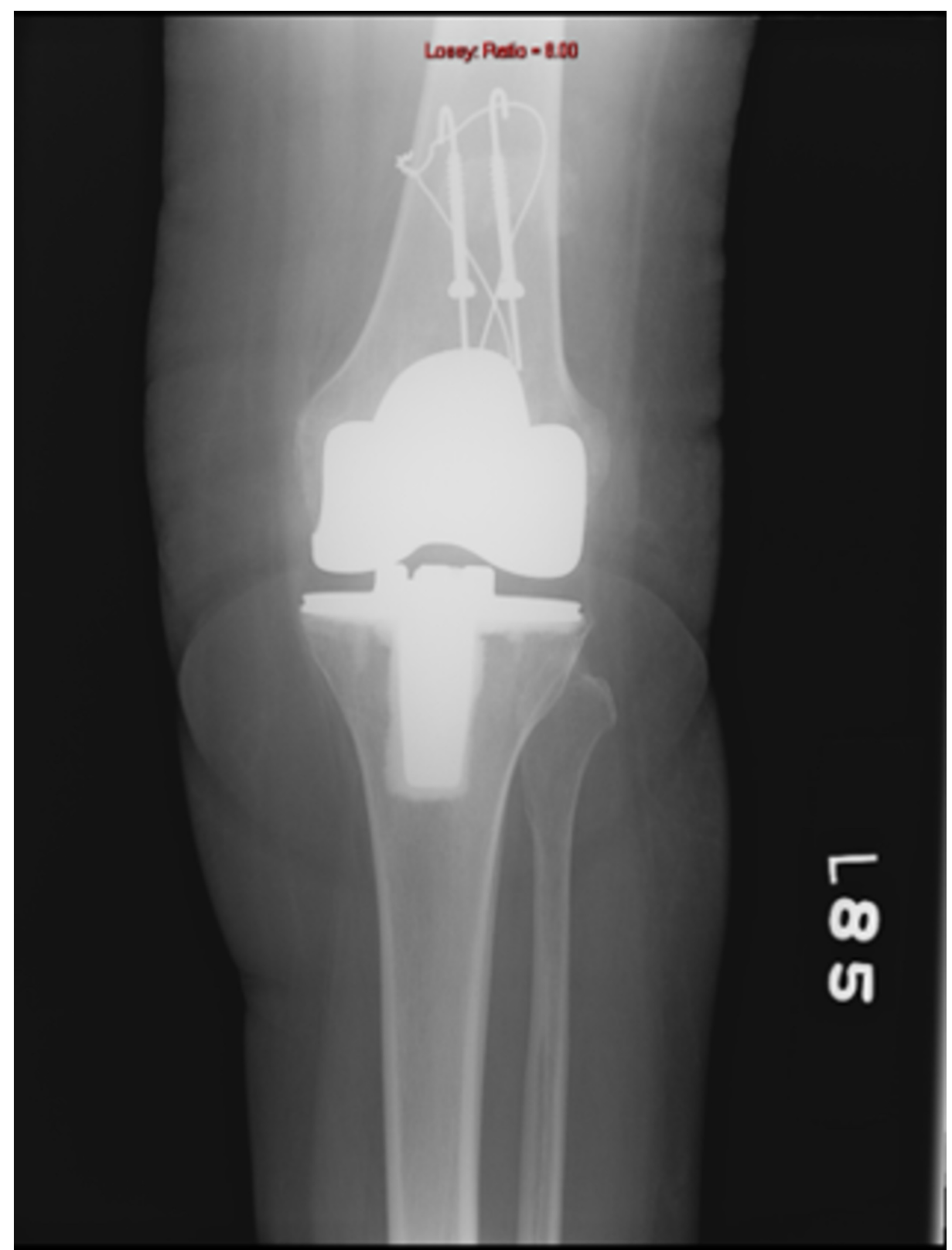

FIGURE 7: Anteroposterior view

This fact signifies the basic difference between a periprosthetic fracture of the patella and traumatic fractures of the native patella. This high failure rate is related to poor bone stock and vascularity. The high failure rate, in addition to the potential of hardware-related complications like breakage and prominent hardware, makes ORIF an inappropriate choice. Partial excision of the patellar fragment with or without repair of the extensor mechanism, as needed, is the mainstay of the operative treatment of patients with periprosthetic patellar who are symptomatic. In cases of a resurfaced patella, integrity and tracking of the patellar prosthesis should be addressed in addition to the extensor mechanism reconstruction. Whenever the patellar component is loose, it should be removed. Further reconstruction is based on available bone stock and the quality of the remaining bone. If an adequate bone stock is available (at least $12 \mathrm{~mm}$ ), patellar resurfacing may be a viable option. Nowadays, with some newer designs (e.g., trabecular metal components), resurfacing may be considered in selected cases with lower bone stock [10].

\section{Patellar Tendon Rupture or Avulsion}

Partial disruptions with less than 30 degrees of extensor lag can be treated non-surgically in the same line as described in previous sections. Patients with more significant extensor lag should be treated surgically, provided there are no contraindications [17]. 


\section{Cureus}

extensor mechanism and inadequate soft tissue coverage available locally.

Direct repair almost always fails and leads to unacceptable outcomes. The main reason for failure is the paucity of soft tissue to achieve adequate strength to withstand the forces during ambulation, which are concentrated on a relatively small area. The vascularity of the tendon is usually poor due to repetitive parapatellar arthrotomies performed in the past. In many cases, there is component malalignment responsible for excessive stress on the extensor mechanism. For these reasons, direct repair is rarely performed nowadays for chronic disruptions and some sort of augmentation is usually considered. Acute patellar tendon avulsions can be treated with either soft tissue repair or direct repair to the bone using drill holes or suture anchors [21]. Acute mid-substance tears can be treated with end-to-end repair, usually augmented by the semimembranosus, gracilis, or Achilles tendon. Table 3 depicts the studies related to local flap augmentation for extensor mechanism disruptions.

\begin{tabular}{|c|c|c|c|c|}
\hline Study & Technique & $\mathbf{N}$ & Results & Conclusion \\
\hline $\begin{array}{l}\text { Whiteside } \\
\text { et al. [22] }\end{array}$ & $\begin{array}{l}\text { Vastus medialis (VM) and vastus lateralis }(\mathrm{VL}) \\
\text { flap reconstruction with or without soleus or } \\
\text { gastrocnemius (GN) }\end{array}$ & 8 & $\begin{array}{l}\text { Mean extension lag } 22^{\circ}\left(5^{\circ}\right. \\
\left.-65^{\circ}\right) \text {; lag is less when } \\
\text { gastrocnemius or soleus } \\
\text { transfer was performed }\end{array}$ & $\begin{array}{l}\text { VM and VL flaps can cover anterior } \\
\text { defects but extensor lag remains an } \\
\text { issue unless GN and/or soleus are } \\
\text { also transferred. }\end{array}$ \\
\hline $\begin{array}{l}\text { Whiteside } \\
\text { et al. [23] }\end{array}$ & $\begin{array}{l}\text { Vastus medialis (VM) and vastus lateralis }(\mathrm{VL}) \\
\text { flap reconstruction with medial gastrocnemius } \\
\text { (GN) flap for extensive defects closed by failed } \\
\text { allograft reconstruction }\end{array}$ & 5 & $\begin{array}{l}\text { Mean extensor lag: } 47^{\circ} \\
\text { preoperative to } 12^{\circ} \\
\text { postoperative at } 1 \text { year }\end{array}$ & $\begin{array}{l}\text { Medial GN flap, in addition to VM and } \\
\text { VL flaps, provide a robust site for } \\
\text { tendon reconstruction in cases of } \\
\text { failed allograft reconstruction }\end{array}$ \\
\hline $\begin{array}{l}\text { Busfield } \\
\text { et al. [24] }\end{array}$ & $\begin{array}{l}\text { mechanism loss with (N:7) or without (N:2) } \\
\text { arthroplasty }\end{array}$ & 9 & $\begin{array}{l}\text { Average lag: } 13.5^{\circ} \text {. } \\
\text { Independent ambulation in } \\
\text { all patients }\end{array}$ & $\begin{array}{l}\text { GN flap can provide adequate } \\
\text { coverage with reasonable outcomes } \\
\text { and may alleviate the need for an } \\
\text { allograft }\end{array}$ \\
\hline $\begin{array}{l}\text { Cadambi } \\
\text { et al. [25] }\end{array}$ & Semitendinosus muscle autograft & 7 & $\begin{array}{l}\text { Average extensor lag: } 8.7^{\circ} \text {. } \\
\text { Average improvement in } \\
\text { HSS Knee Society score: } \\
72 \text { postoperatively }\end{array}$ & $\begin{array}{l}\text { This technique can restore function } \\
\text { and is better than direct repair and } \\
\text { suture anchor reconstruction }\end{array}$ \\
\hline
\end{tabular}

TABLE 3: Results of Local Soft Tissue Augmentation for Extensor Mechanism Reconstruction HSS: Hospital for Special Surgery; N: number

Chronic patellar tendon ruptures usually require augmentation in the form of allograft, autograft, or various synthetic materials. Bone-patellar tendon-bone grafts, Achilles tendon allografts, and synthetic materials, such as polypropylene mash, have been tried to augment the repair with variable success. Figures 8-12 show a technique for repair of chronic patellar tendon rupture in a patient with distal femur replacement using bone-patellar tendon allograft. 


\section{Cureus}

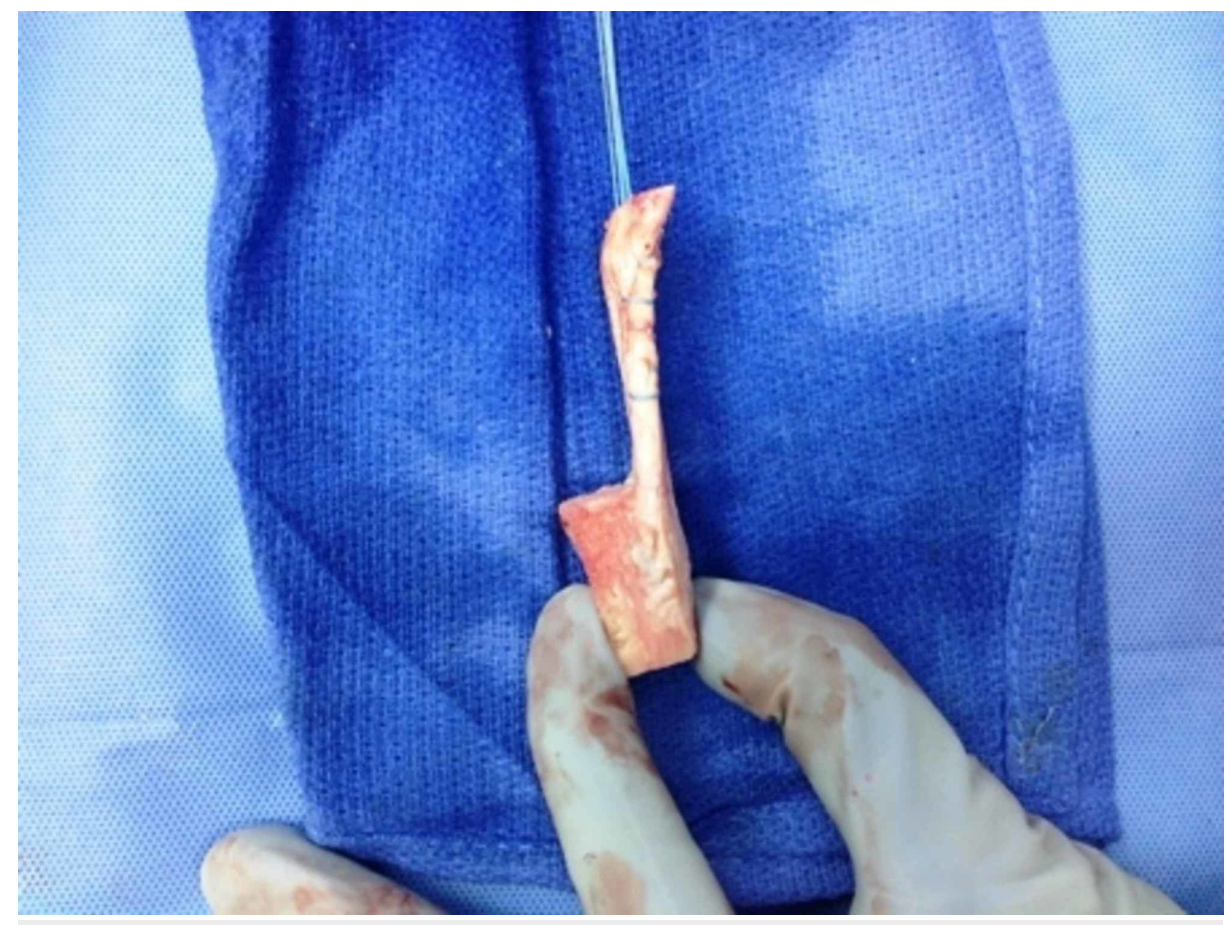

FIGURE 8: Patellar tendon-bone allograft with Krackow sutures passed through the patellar tendon

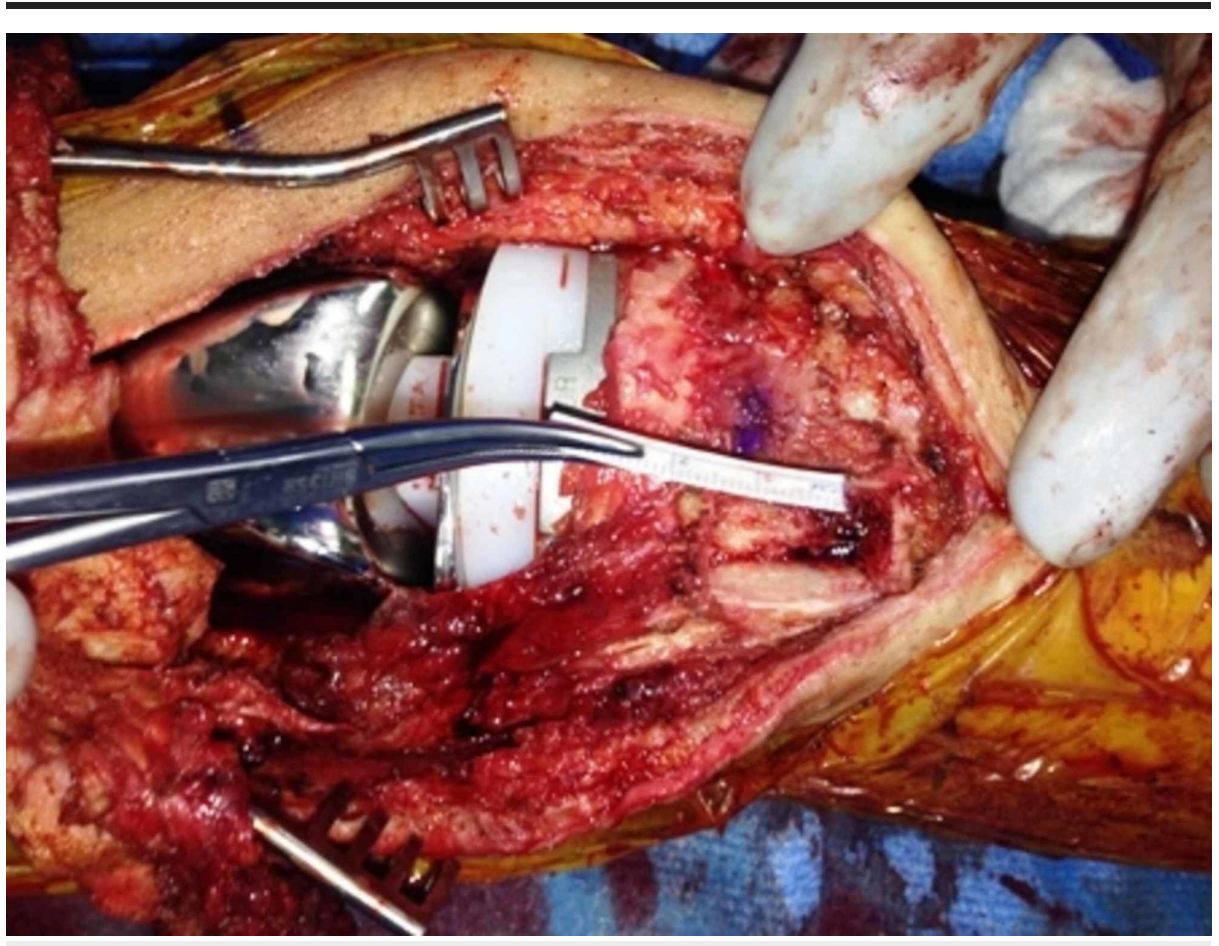

FIGURE 9: Trough in the proximal tibia for fixation of the allograft bone block 


\section{Cureus}

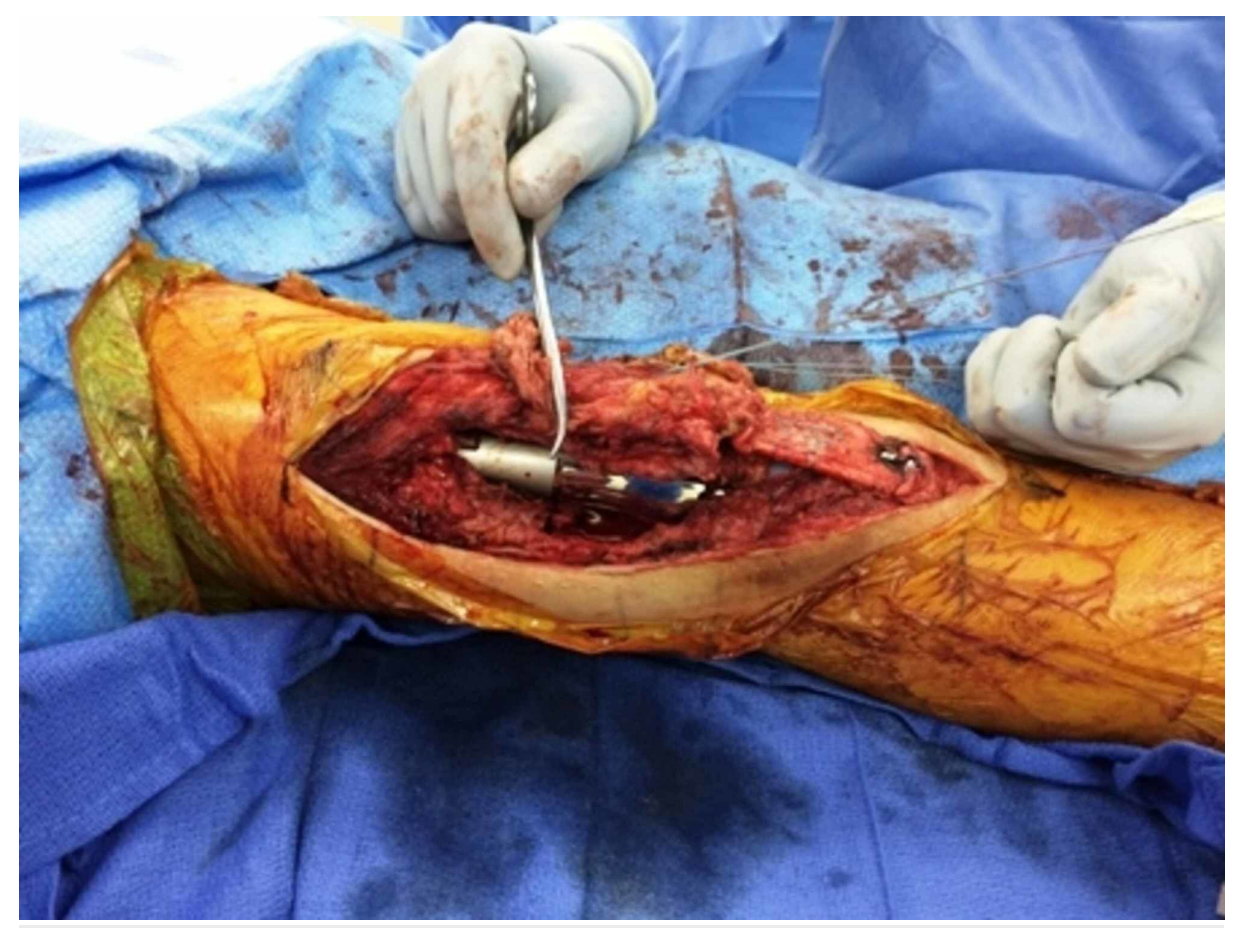

FIGURE 10: Fixation of the allograft bone block to the tibia using two $3.5 \mathrm{~mm}$ screws; attachment of the allograft tendon to the lower pole of the patella through the bone tunnel using FiberWire ${ }^{\circledR}$ sutures (Arthrex, Inc., Naples, FL)

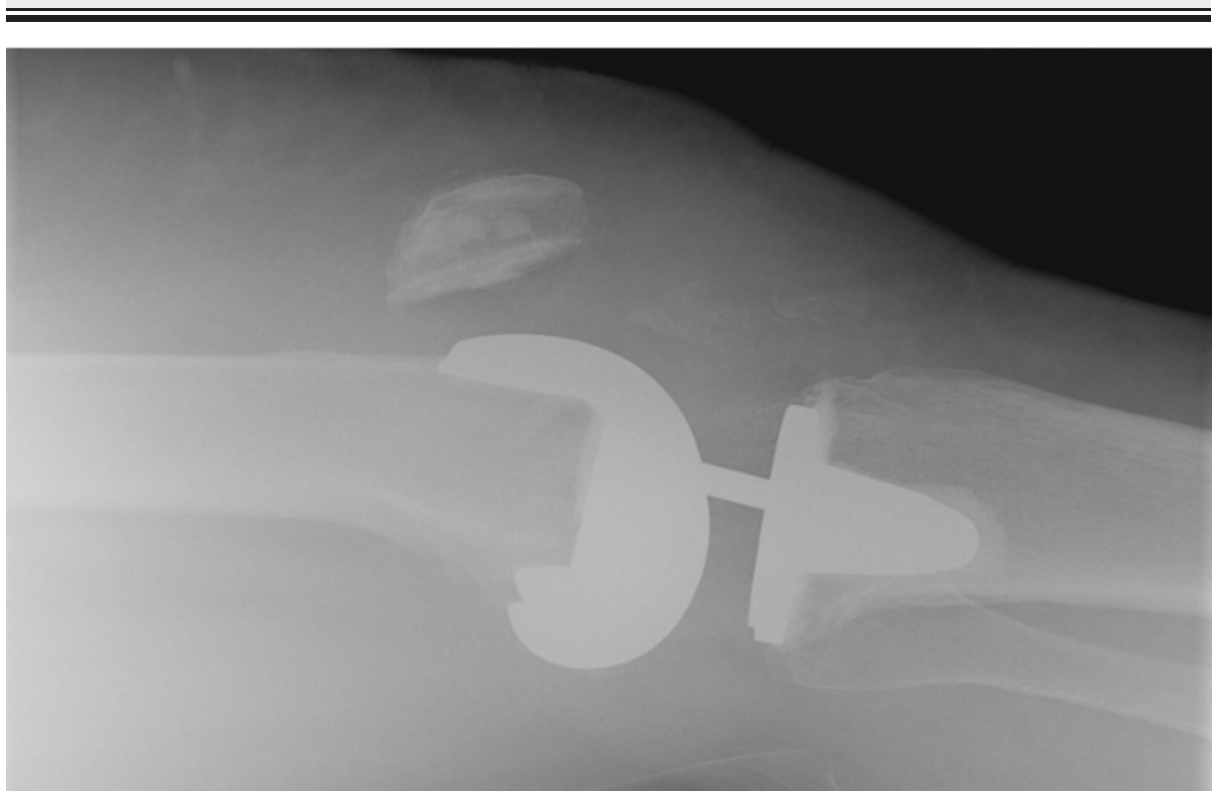

FIGURE 11: Preoperative lateral $x$-ray showing a patella alta 


\section{Cureus}

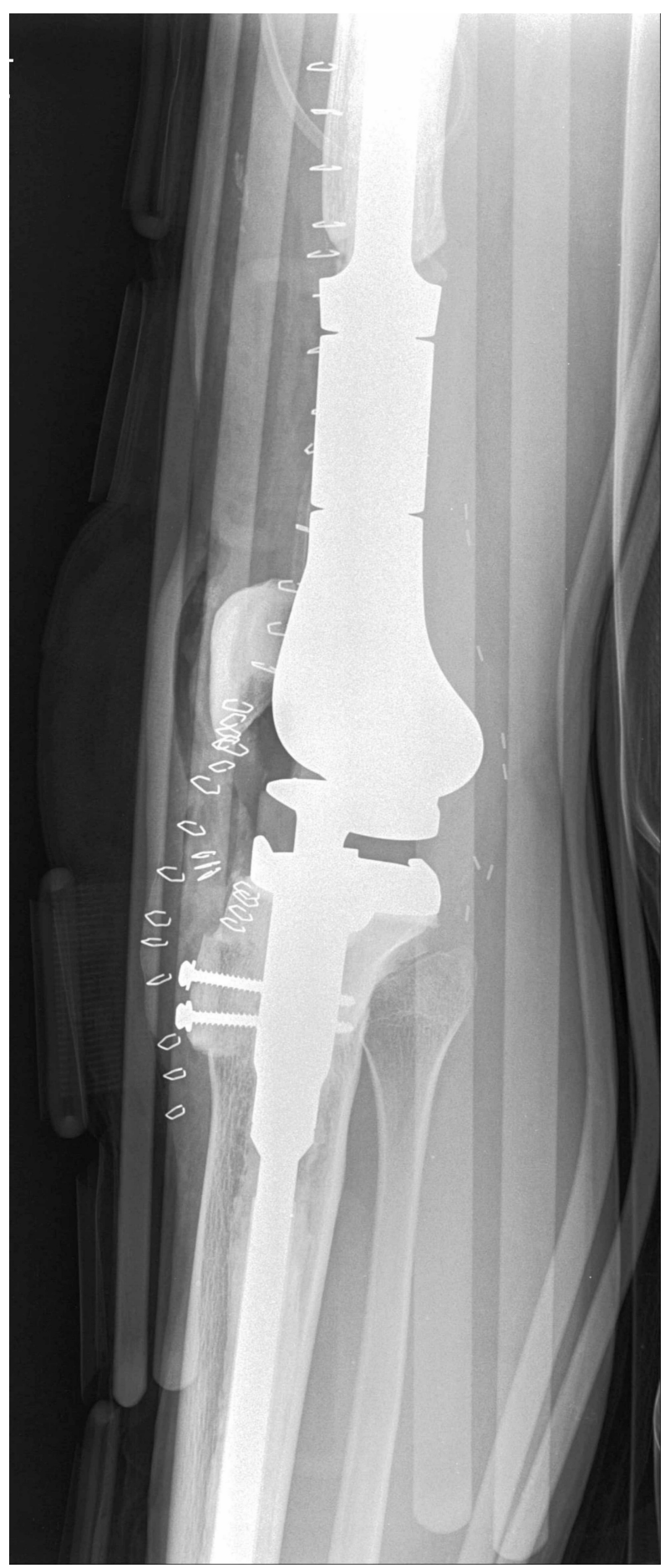

FIGURE 12: Fixation of the allograft bone block to the tibia using two screws and correction of the patella alta

Synthetic material appears to be a potential alternative to allografts since they do not depend upon the availability of local muscle flaps, is more cost-effective, and yields similar results in an early study (Table 4) [25]. 


\section{Cureus}

\begin{tabular}{|c|c|c|c|c|}
\hline Study & Technique & $\mathbf{N}$ & Results & Conclusion \\
\hline $\begin{array}{l}\text { Browne } \\
\text { et } \\
\text { al. [26] }\end{array}$ & $\begin{array}{l}\text { Knitted } \\
\text { monofilament } \\
\text { polypropylene graft } \\
\text { (Marlex mesh*) }\end{array}$ & 13 & $\begin{array}{l}\text { Mean lag was less than } 10^{\circ} \text { in } 9 \text { survived grafts; } 3 \\
\text { patients failed reconstruction and needed reoperation; } 1 \\
\text { patient ended up with arthrodesis for infection }\end{array}$ & $\begin{array}{l}\text { Marlex mesh is significantly } \\
\text { inexpensive in comparison to } \\
\text { allograft and yields equivalent } \\
\text { results }\end{array}$ \\
\hline
\end{tabular}

TABLE 4: Results of Synthetic Material Reconstruction for Patellar Tendon Dysfunction

Figures 13 and 14 show the operative technique for repair of chronic extensor mechanism disruption using the Marlex mesh (Becton, Dickinson \& Co., E. Rutherford, NJ).

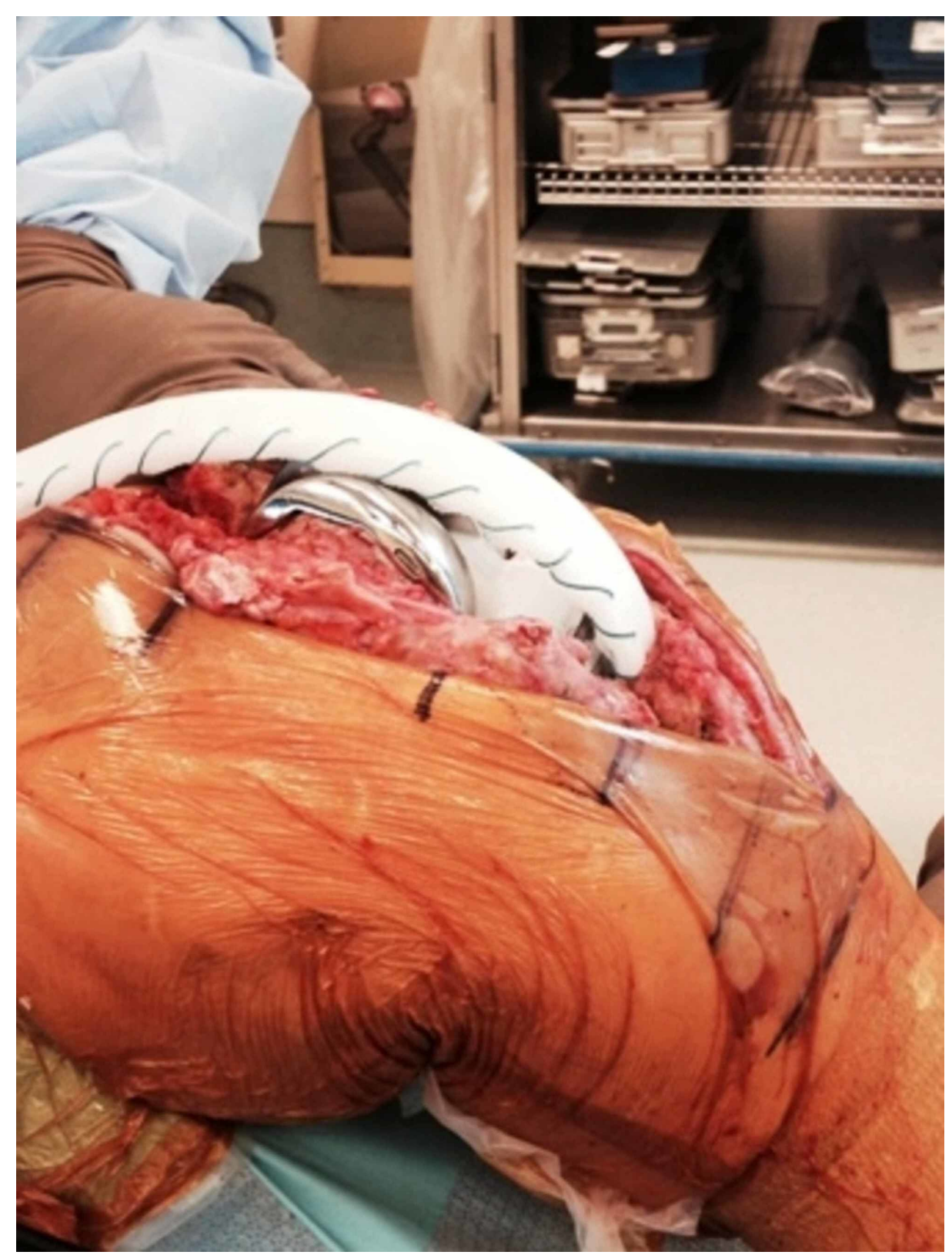

FIGURE 13: Tubularized Marlex mesh is fixed to a trough made in the proximal tibia using cement 


\section{Cureus}

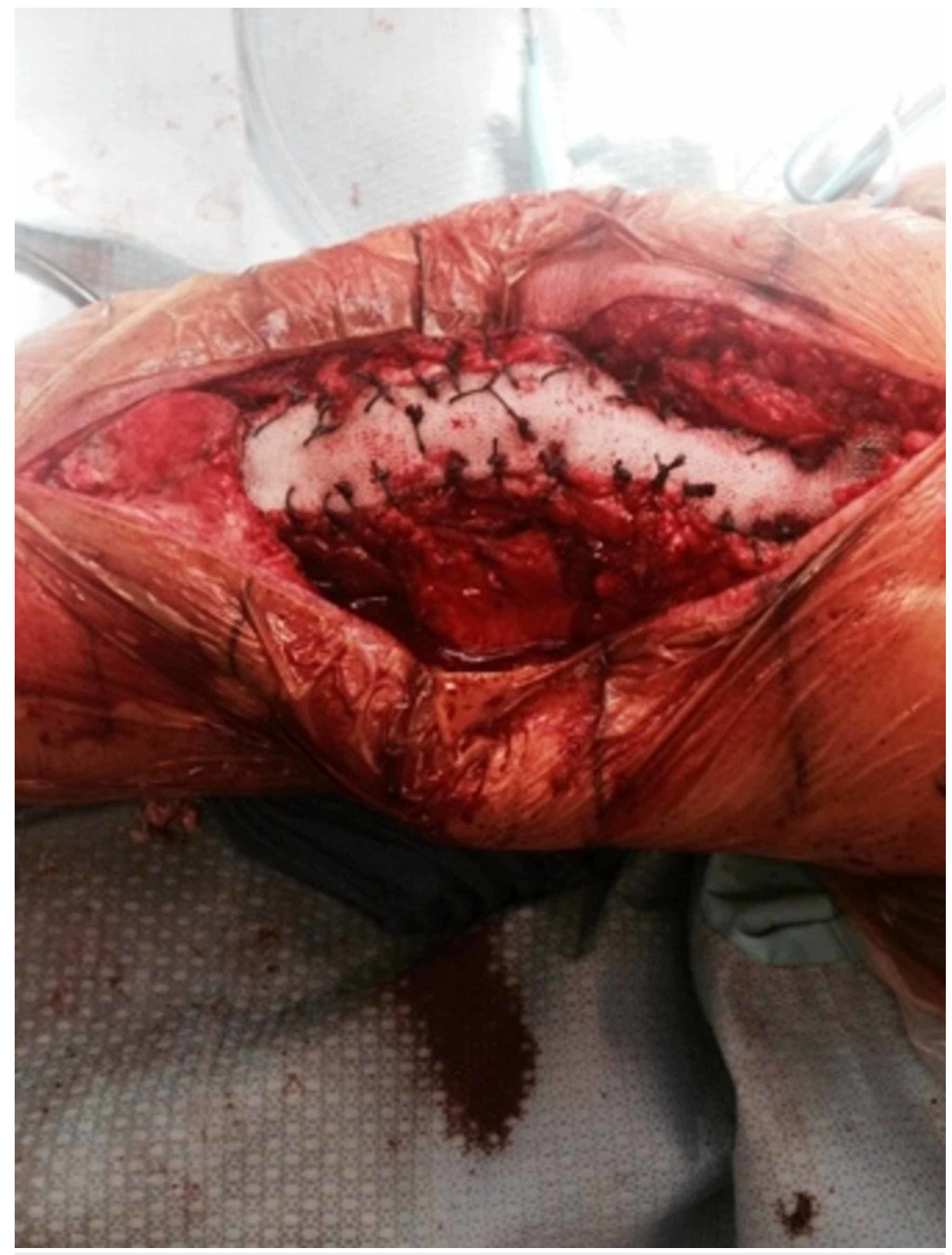

FIGURE 14: Final attachment of the Marlex mesh to the medial and lateral retinacula and quadriceps tendon with Ethibond sutures with the knee in full extension and maximum tension

Ethibond sutures (Johnson \& Johnson, New Brunswick, NJ)

A chronic retracted patellar tendon with extensive scarring and soft tissue or bone loss can be treated with an extensor mechanism allograft. This procedure is technically challenging and is associated with high failure and complication rates. Some of the studies are listed in Table 5 and show results of allograft reconstruction for patellar tendon disruptions. To date, allograft reconstruction is considered the gold standard technique for chronic patellar tendon disruptions. However, on long-term follow-up, the results deteriorate because of immune reaction and resultant fibrous changes which lead to the development of late extensor lag. Better substitutes for allograft should be a focus of further results because of the high cost, risks of infection, and immune-mediated late failures. 


\section{Cureus}

\begin{tabular}{|c|c|c|c|c|}
\hline Study & Technique & $\mathbf{N}$ & Results & Conclusion \\
\hline $\begin{array}{l}\text { Malhotra } \\
\text { et } \\
\text { al. [27] }\end{array}$ & $\begin{array}{l}\text { Patella-patellar tendon-tibial } \\
\text { tubercle composite allograft }\end{array}$ & 4 & One patient had a $10^{\circ}$ lag & $\begin{array}{l}\text { Provided with an optimum } \\
\text { environment for bony healing and } \\
\text { supervised physical therapy } \\
\text { protocol, this technique can produce } \\
\text { good results }\end{array}$ \\
\hline $\begin{array}{l}\text { Burnett } \\
\text { et al. } \\
\text { [28] }\end{array}$ & $\begin{array}{l}\text { Quadriceps tendon-patella- } \\
\text { patellar tendon-tibial tubercle } \\
\text { allograft or Achilles tendon } \\
\text { allograft }\end{array}$ & 19 & $\begin{array}{l}\text { Mean lag } 14^{\circ}, 89 \% \text { satisfaction rate; } 15 \\
\text { patients had }<15^{\circ} \text { lag }\end{array}$ & $\begin{array}{l}\text { Both the allografts provided } \\
\text { satisfactory functional outcomes }\end{array}$ \\
\hline $\begin{array}{l}\text { Burnett } \\
\text { et } \\
\text { al. [29] }\end{array}$ & $\begin{array}{l}\text { Quadriceps tendon-patella- } \\
\text { patellar tendon-tibial tubercle } \\
\text { allograft; Without tension (Group } \\
\text { I: 7) and with tension (Group 2: 13) }\end{array}$ & 20 & $\begin{array}{l}\text { Group I: Average extensor lag: } 59^{\circ} \text { and } \\
\text { HSS knee score: } 52 \text {; Group II: Average } \\
\text { extensor lag } 4.3^{\circ} \text { and HSS knee score: } 88 \text {; } \\
\text { No loss of flexion in either group. }\end{array}$ & $\begin{array}{l}\text { Repair without tension is tantamount } \\
\text { to failure when allograft is used for } \\
\text { reconstruction }\end{array}$ \\
\hline $\begin{array}{l}\text { Barrack } \\
\text { et } \\
\text { al. [30] }\end{array}$ & $\begin{array}{l}\text { Achilles tendon allograft (N: } 8 \text {; } \\
\text { Quadriceps tendon-patella- } \\
\text { patellar tendon-tibial tubercle } \\
\text { allograft (N: } 6)\end{array}$ & 14 & $\begin{array}{l}\text { Lag }<10^{\circ}: 10 \text { pts.; Lag }-15^{\circ}: 2 \text { pts.; Lag - } \\
30^{\circ}: 1 \text { pt.; Lag }-45^{\circ}: 1 \text { pt.; All patients } \\
\text { remained ambulatory }\end{array}$ & $\begin{array}{l}\text { Improved functional results and } \\
\text { patient satisfaction with this } \\
\text { technique }\end{array}$ \\
\hline $\begin{array}{l}\text { Crossett } \\
\text { et } \\
\text { al. [31] }\end{array}$ & $\begin{array}{l}\text { Achilles tendon allograft, Group I: } \\
\text { Primary TKA (N:5); Group II: } \\
\text { Revision TKA (N:4) }\end{array}$ & 9 & $\begin{array}{l}\text { Improvement in knee functional score } \\
\text { Group I: } 26 \text { to } 81 \text {; Group II: } 14 \text { to } 53 \text {; } \\
\text { Average extensor lag: } 44^{\circ} \text { to } 3^{\circ} ; 2 \text { failures } \\
\text { with successful repairs }\end{array}$ & $\begin{array}{l}\text { Once healed, Achilles allograft can } \\
\text { serve as a reliable reconstruction, at } \\
\text { least at short-term }\end{array}$ \\
\hline $\begin{array}{l}\text { Nazarian } \\
\text { et } \\
\text { al. [32] }\end{array}$ & $\begin{array}{l}\text { Quadriceps tendon-patella- } \\
\text { patellar tendon-tibial tubercle } \\
\text { allograft }\end{array}$ & 40 & $\begin{array}{l}\text { Average lag } 13^{\circ}, 8 \text { patients had a rupture } \\
\text { and repeat reconstruction; Knee Society } \\
\text { Score improvement: } 34 \text { to } 36\end{array}$ & $\begin{array}{l}\text { Results support the use of this } \\
\text { technique over the direct repair }\end{array}$ \\
\hline $\begin{array}{l}\text { Emerson } \\
\text { et } \\
\text { al. [33] }\end{array}$ & Extensor mechanism allograft & 15 & $\begin{array}{l}\text { No lag: } 6 \text { patients; Graft rupture: } 1 \text { patient; } \\
\text { Early quadriceps junction failure: } 1 \\
\text { patient; Patellar component loosening: } 1 \text {; } \\
\text { Average postoperative clinical score: } 78\end{array}$ & $\begin{array}{l}\text { Satisfactory outcomes from allograft } \\
\text { reconstruction }\end{array}$ \\
\hline $\begin{array}{l}\text { Emerson } \\
\text { et } \\
\text { al. [34] }\end{array}$ & $\begin{array}{l}\text { Quadriceps tendon-patella- } \\
\text { patellar tendon-tibial tubercle } \\
\text { allograft }\end{array}$ & 13 & $\begin{array}{l}\text { Minimal extensor lag: } 3 \text { patients; Failures: } \\
3 \text { patients required reoperation }\end{array}$ & $\begin{array}{l}\text { Satisfactory outcomes from allograft } \\
\text { reconstruction }\end{array}$ \\
\hline
\end{tabular}

\section{TABLE 5: Results of allograft reconstruction for patellar tendon dysfunction}

HSS: Hospital for Special Surgery; N: number; pts: patients; TKA: total knee arthroplasty

Management of failed allograft reconstruction is truly challenging. There is a paucity of available literature in this area. In a published study, eight cases of allograft failures were re-operated using allografts [35]. Two out of the eight cases failed due to infection and the remaining six showed no clinical improvement. Repetitive surgeries further compromise the soft tissue envelope and increase the risk of infection. In refractory cases, knee fusion or amputation may be appropriate choices. The decision should be made only after due consideration of the patient's expectations, physiological condition, and anticipated outcomes.

\section{Conclusions}

There are many techniques described in the literature to treat extensor mechanism discontinuity. Lack of unanimity between experts probably shows the complexity of this problem and the guarded prognosis of the condition.

In summary, non-operative treatment for partial disruptions at any anatomical location results in acceptable outcomes. For complete disruptions, treatment depends upon the location, extent, and chronicity of the disruption, the patient's overall health condition and expectations, and the experience and expertise of the operating surgeon.

Every surgeon should adopt the technique that works well in his or her hands. It is also important to discuss 
all the aspects of the condition (e.g., treatment options, nature of the treatment, rehabilitation, and possible outcomes) in detail with the patient to bring mutual expectations to a pragmatic level.

\section{Additional Information \\ Disclosures}

Conflicts of interest: In compliance with the ICMJE uniform disclosure form, all authors declare the following: Payment/services info: All authors have declared that no financial support was received from any organization for the submitted work. Financial relationships: All authors have declared that they have no financial relationships at present or within the previous three years with any organizations that might have an interest in the submitted work. Other relationships: All authors have declared that there are no other relationships or activities that could appear to have influenced the submitted work.

\section{References}

1. Berger RA, Crossett LS, Jacobs JJ, Rubash HE: Malrotation causing patellofemoral complications after total knee arthroplasty. Clin Orthop Relat Res. 1998, 356:144-53. 10.1097/00003086-199811000-00021

2. Liu HW, Gu WD, Xu NW, Sun JY: Surgical approaches in total knee arthroplasty: a meta-analysis comparing the midvastus and subvastus to the medial peripatellar approach. J Arthroplasty. 2014, 29:2298-304. 10.1016/j.arth.2013.10.023

3. Younger AS, Duncan CP, Masri BA: Surgical exposures in revision total knee arthroplasty. J Am Acad Orthop Surg. 1998, 6:55-64. 10.5435/00124635-199801000-00006

4. Cooney WP 4th, Sierra RJ, Trousdale RT, Pagnano MW: Revision total knees done for extensor problems frequently require reoperation. Clin Orthop Relat Res. 2005, 440:117-21. 10.1097/01.blo.0000187527.28686.2d

5. Dobbs RE, Hanssen AD, Lewallen DG, Pagnano MW: Quadriceps tendon rupture after total knee arthroplasty: prevalence, complications, and outcomes. J Bone Joint Surg Am. 2005, 87:37-45. 10.2106/00004623-200501000-00007

6. Healy WL, Wasilewski SA, Takei R, Oberlander M: Patellofemoral complications following total knee arthroplasty. Correlation with implant design and patient risk factors. J Arthroplasty. 1995, 10:197-201. 10.1016/s0883-5403(05)80127-5

7. Trepte CT, Kirgis A: Spontaneous ruptures of the extensor system of the knee following joint replacement in patients with rheumatoid arthritis (Article in German). Z Orthop Unfall. 1988, 126:519-25. 10.1055/s2008-1044477

8. Lynch AF, Rorabeck CH, Bourne RB: Extensor mechanism complications following total knee arthroplasty. J Arthroplasty. 1987, 2:135-40. 10.1016/S0883-5403(87)80020-7

9. Berry DJ: Epidemiology: hip and knee. Orthop Clin North Am. 1999, 30:183-90. 10.1016/s00305898(05)70073-0

10. Chalidis BE, Tsiridis E, Tragas AA, Stavrou Z, Giannoudis PV: Management of periprosthetic patellar fractures. A systematic review of literature. Injury. 2007, 38:714-24. 10.1016/j.injury.2007.02.054

11. Keating EM, Haas G, Meding JB: Patella fracture after post total knee replacements . Clin Orthop Relat Res. 2003, 416:93-97. 10.1097/01.blo.0000092992.90435.20

12. Figgie HE 3rd, Goldberg VM, Figgie MP, Inglis AE, Kelly M, Sobel M: The effect of alignment of the implant on fractures of the patella after condylar total knee arthroplasty. J Bone Joint Surg Am. 1989, 71:1031-39. 10.2106/00004623-198971070-00009

13. Goldberg VM, Figgie HE 3rd, Inglis AE, Figgie MP, Sobel M, Kelly M, Way M: Patellar fracture type and prognosis in condylar total knee arthroplasty. Clin Orthop Relat Res. 1988, 236:115-22. 10.1097/00003086198811000-00013

14. Ortiguera CJ, Berry DJ: Patellar fracture after total knee arthroplasty. J Bone Joint Surg Am. 2002, 84:532-40. 10.2106/00004623-200204000-00004

15. Kelly MA: Extensor mechanism complications in total knee arthroplasty. Instr Course Lect. 2004, 53:193-99.

16. Dalury DF, Dennis DA: Extensor mechanism problems following total knee replacement. J Knee Surg. 2003, 16:118-22.

17. Rosenberg AG: Management of extensor mechanism rupture after TKA. J Bone Joint Surg Br. 2012, 94:11619. 10.1302/0301-620X.94B11.30823

18. Kim TW, Kamath AF, Israelite CL: Suture anchor repair of quadriceps tendon rupture after total knee arthroplasty. J Arthroplasty. 2011, 26:817-20. 10.1016/j.arth.2011.01.006

19. Gitomirski ML, Finn HA: Medial gastrocnemius flap for reconstruction of knee extensor mechanism disruption after total knee replacement (TKR). Surg Technol Int. 2004, 12:221-28.

20. Larsen E, Lund PM: Ruptures of the extensor mechanism of the knee joint: clinical results and patellofemoral articulation. Clin Orthop Relat Res. 1986, 213:150-53. 10.1097/00003086-198612000-00018

21. Kamath AF, Shah RP, Summers N, Israelite CL: Suture anchor repair of patellar tendon rupture after total knee arthroplasty. J Knee Surg. 2013, 26:128-31.

22. Whiteside LA: Surgical technique: vastus medialis and vastus lateralis as flap transfer for knee extensor mechanism deficiency. Clin Orthop Relat Res. 2013, 471:221-30. 10.1007/s11999-012-2532-z

23. Whiteside LA: Surgical technique: muscle transfer restores extensor function after failed patella-patellar tendon allograft. Clin Orthop Relat Res. 2014, 472:218-26. 10.1007/s11999-013-3101-9

24. Busfield BT, Huffman GR, Nahai F, Hoffman W, Ries MD: Extended medial gastrocnemius rotational flap for treatment of chronic knee extensor mechanism deficiency in patients with and without total knee arthroplasty. Clin Orthop Relat Res. 2004, 428:190-97. 10.1097/01.blo.0000148593.44691.30

25. Cadambi A, Engh GA: Use of a semitendinosus tendon autogenous graft for rupture of the patellar ligament after total knee arthroplasty. A report of seven cases. J Bone Joint Surg Am. 1992, 74:974-79. 10.2106/00004623-199274070-00003 


\section{Cureus}

26. Browne JA, Hanssen AD: Reconstruction of patellar tendon disruption after total knee arthroplasty: results of a new technique utilizing synthetic mesh. J Bone Joint Surg Am. 2011, 93:1137-43. 10.2106/JBJS.J.01036

27. Malhotra R, Garg B, Logani V, Bhan S: Management of extensor mechanism deficit as a consequence of patellar tendon loss in total knee arthroplasty: a new surgical technique. J Arthroplasty. 2008, 23:1146-51. 10.1016/j.arth.2007.08.011

28. Burnett RS, Butler RA, Barrack RL: Extensor mechanism allograft reconstruction in TKA at a mean of 56 months. Clin Orthop Relat Res. 2006, 452:159-65. 10.1097/01.blo.0000238818.25530.2b

29. Burnett RS, Berger RA, Paprosky WG, Della Valle CJ, Jacobs JJ, Rosenberg AG: Extensor mechanism allograft reconstruction after total knee arthroplasty. A comparison of two techniques. J Bone Joint Surg Am. 2004, 86:2694-99. 10.2106/00004623-200412000-00016

30. Barrack RL, Stanley T, Allen Butler R: Treating extensor mechanism disruption after total knee arthroplasty. Clin Orthop Relat Res. 2003, 416:98-104. 10.1097/01.blo.0000092993.90435.69

31. Crossett LS, Sinha RK, Sechriest VF, Rubash HE: Reconstruction of a ruptured patellar tendon with achilles tendon allograft following total knee arthroplasty. J Bone Joint Surg Am. 2002, 84:1354-61. 10.2106/00004623-200208000-00011

32. Nazarian DG, Booth RE Jr: Extensor mechanism allografts in total knee arthroplasty. Clin Orthop Relat Res. 1999, 367:123-29. 10.1097/00003086-199910000-00015

33. Emerson RH Jr, Head WC, Malinin TI: Extensor mechanism reconstruction with an allograft after total knee arthroplasty. Clin Orthop Relat Res. 1994, 303:79-85. 10.1097/00003086-199406000-00010

34. Emerson RH Jr, Head WC, Malinin TI: Reconstruction of patellar tendon rupture after total knee arthroplasty with an extensor mechanism allograft. Clin Orthop Relat Res. 1990, 260:154-61. 10.1097/00003086-199011000-00026

35. Lewullis GE, Jasko JG, Booth RE 3rd, Lonner JH: Revision extensor mechanism allografting after total knee arthroplasty. Am J Orthop (Belle Mead NJ). 2010, 39:539-42. 